\title{
METHODOLOGICAL GUIDELINES FOR ORGANIZING AND CONDUCTING WORKSHOPS ON THE FUNDAMENTALS OF MENTOR ACTIVITIES FOR FUTURE MARINE OFFICERS
}

\author{
Vitalii Yarema ${ }^{1}$ \\ ${ }^{1}$ Head of the department of organization of material resources provision, Deputy Service Support Chief for \\ Logistics Command, Ukrainian Ground Forces Command of the Armed Forces of Ukraine, Odesa, Ukraine, \\ e-mail: yarema.vit1975@gmail.com, ORCID: https://orcid.org/0000-0002-6984-4119
}

Abstract. The aim of the article is to theoretically substantiate methodological guidelines to scientific and pedagogical staff of the Military Academy (Odesa) on the organization and carrying out of workshops with future Marine officers in the context of formation of readiness of the specified category of servicemen for mentoring.

Methods of research: use of analysis and synthesis of scientific literature, regulatory legal documents, curricula and educational programmes, as well as expert evaluation.

The results obtained: the research found that in the system of forming a positive attitude of future Marine officers to mentoring, their expertise of the conceptual apparatus and system of theoretical knowledge about mentoring, its variability and peculiarities of implementation in the military staff, communication and organizational skills development, as well as the ability to reorient the purpose and content of mentoring to specific service tasks, which are determined by the conditions of military service of marine units, the interests of the mentees an important component is organization and conduction of appropriate training.

Practical use: based on the results of scientific research, specific advice was developed for scientific and pedagogical staff of the Military Academy (Odesa) on organizing and conducting workshops with future Marine officers in the context of forming the readiness of this category of servicemen for mentoring (as part of the special course programme "Fundamentals of Mentoring in Marine Units" designed for cadets of the faculty of training specialists of airborne assault troops).

Keywords: future Marine officers, methodological guidelines, mentoring, organization, conducting, workshop.

JEL Classification: JEL I0; I20

Formulas: 0; fig.: 0, tabl.: 2; bibl.: 7

Introduction. Effective development of the security and defense sector in the present conditions of intensifying training and professionalization of personnel involves the implementation of a set of tasks, which include: introduction of an integrated education system, combat and special training of personnel in the security and defense sector; formation of a new safety culture while maintaining specialization and individualization of the training system; raising the professional level of personnel for security and defense sector. Considering the above mentioned the main directions of development of the components of the security and defense sector, in particular the Armed Forces of Ukraine, are the improvement of the training system of troops (forces); gradual adaptation of the Armed Forces of Ukraine to NATO standards in terms of training, technical equipment and comprehensive support. Implementation of the outlined directions in the context of improving the training system involves changing approaches to the formation of professional competencies, the transition from traditional to modern education system using pedagogical approaches (including sets of workshops), adapted to the peculiarities of military service. The application of a workshop in the modern system of professional 
education of future Marine officers is aimed at activating the full range of personal and professionally significant qualities of these specialists, their knowledge, skills and habits. The system of workshops with the corresponding programmes of their implementation is a modern interactive approach in realization of information and educational activity, and the effectiveness of its introduction is caused by competence and readiness of the personnel for conducting such workshops.

Literature Review. The issue of improving the methods of training future professionals in a particular specialty is constantly reflected in both psychological and pedagogical research.

The constant increase in the amount of information and limited time to grasp it, informatization of society, rapid development of technical means of education, as well as a number of other factors provides the necessity to actively use the modern methods and approaches for special (professional) competencies. The effective components in training future professionals to carry out a certain type of activity are training technologies, which, according to T. Kotenko, is a key element of active learning methods [1, p. 143-147]. However, it should be noted that for some researchers the workshop forms of education mean the creation of a system of workshops on the specialty, which is conducted along with special training and which also reflects the main problems and issues of the academic subject [2].

The essence and classification of workshop methods (forms), basic concepts, components, motivational aspects of workshop, methodological approaches to creating workshops and their models, algorithms for their implementation, as well as other aspects of workshop education are sufficiently reflected in the researches of native and foreign scientists, including S. Almashi [3], M. Artiushyna [4], R. Barkly, D. Kaple [5], N. Butenko [6]. Methodological guidelines for coaches on the development and conducting of training sessions became the subject of research of T. Fulei, N. Burukovska, H. Savchenko [7]. The main attention of researchers is focused on methodological aspects of the organization of workshop forms of training, peculiarities of the organization of business workshops, the characteristics of theoretical and methodological aspects of the organization and carrying out of management workshops. However, despite the significant contribution of researchers and the importance of the outlined scientific papers, the issue of effective implementation of workshop approaches in the educational process in general and training of future Marine officers for mentoring in particular remains insufficiently clarified.

Aims. The aim is to theoretically substantiate methodological guidelines to scientific and pedagogical staff of the Military Academy (Odesa) for organizing and conducting workshops with future Marine officers in the context of forming readiness for mentoring.

Methods. Application analysis and synthesis of scientific literature, regulatory legal documents, curricula and educational programmes, as well as expert evaluation.

Results. The development of a workshop programme for future officers of the Marine Corps on the fundamentals of mentoring involved consideration of the 
features and principles of servicemen training, the specifics of their service duties, as well as the topical content of the workshop. The main tasks of the workshop, as a component of the system of forming the readiness of future Marine officers for mentoring, include: increasing the level of awareness of the participants of the urgency of the issue of organization and implementation of mentoring activity; activation of the internal need for self-improvement; creating conditions for gaining new experience and its analysis; encouraging workshop participants to work on understanding the importance of mentoring in the system of adaptation of servicemen to the conditions of service; development of communication skills among future Marine officers in order to increase the effectiveness of professional communication; motivating participants to use the experience gained during the workshop in future service.

Discussion. Let us consider the content of the workshop on the fundamentals of mentoring for future Marine officers which is given in Table 1.

Table 1. The content of workshop "Mentoring"

\begin{tabular}{|c|c|}
\hline Aim of workshop & Formation of effective mentoring skills \\
\hline Workshop audience & cadets of the faculty of training specialists of airborne assault troops \\
\hline $\begin{array}{l}\text { The concept of } \\
\text { workshop }\end{array}$ & $\begin{array}{l}\text { One of the effective (minimum costs, maximum result) ways to quickly adapt } \\
\text { young officers (newly appointed) to the conditions of professional activity is } \\
\text { mentoring by more experienced officers. What is the way to provide mentoring } \\
\text { properly? In fact, one ability to do your job correctly is not enough. Skills are } \\
\text { not automatically transferred from one serviceman to another. In order for } \\
\text { mentoring to have a positive result, it is necessary to strictly follow the } \\
\text { mentoring approach. }\end{array}$ \\
\hline $\begin{array}{l}\text { Number of } \\
\text { participants }\end{array}$ & $6-12$ cadets \\
\hline Workshop duration & 2 hours per 2 workshop days \\
\hline $\begin{array}{l}\text { Expected workshop } \\
\text { results }\end{array}$ & $\begin{array}{l}\text { knowledge: principles of training session - the leading role of the learner (the } \\
\text { cadet learns himself, the mentor only helps), reliance on the experience of the } \\
\text { cadet, the application of new knowledge and skills in practice; } \\
\text { skills: to provide mentoring, analysis of the mentees' work according to the } \\
\text { algorithm, to motivate the mentees, to conduct an effective demonstration of the } \\
\text { model of behavior, to practice the skills for the mentees to automatically apply } \\
\text { them. }\end{array}$ \\
\hline Interaction modes & $\begin{array}{l}\text { "Aquarium" - two cadets play, the rest watch; in teams; in threes ("simultaneous } \\
\text { game" session. Two cadets play, the third is an observer); in pairs } \\
\text { ("simultaneous game" session); simulation games, model exercises, large group } \\
\text { discussions; viewing and discussing videos in a large group. It is advisable to } \\
\text { use informational messages during the training session; brainstorming; work in } \\
\text { small groups; exercises; presentations; games; mini-lectures; role play. }\end{array}$ \\
\hline $\begin{array}{l}\text { Workshop teaching } \\
\text { materials }\end{array}$ & $\begin{array}{l}\text { presentation slides; theoretical materials, exercises, "cases", tests; video clips } \\
\text { recorded during the training session; A4 and A1 paper, colored pencils, pens, } \\
\text { colored marker pens, 4-color markers, flipchart, chairs for participants and } \\
\text { coaches. }\end{array}$ \\
\hline
\end{tabular}

We offer you a version of the workshop programme "Mentoring" which is shown in table 2. 


\section{Table 2. Workshop programme "Mentoring"}

\begin{tabular}{|c|c|}
\hline Time & Summary \\
\hline \multicolumn{2}{|r|}{ Training session day 1} \\
\hline $\begin{array}{l}\text { Indicated after } \\
\text { approval }\end{array}$ & $\begin{array}{l}\text { Introduction (announcement of the aim and the procedure (basic rules) of the } \\
\text { training course, study cadets' expectations of the training course) } \\
\text { Mini-lecture "Basic concepts of mentoring" } \\
\text { Group work "Start from scratch" and its discussion } \\
\text { Watch the video clip "Mentor". } \\
\text { Role-play "Fundamentals of mentoring". Filming, discussion the activities of } \\
\text { game participants } \\
\text { Mini-lecture "Basic principles of mentoring" } \\
\text { Role-play "Mentoring", discussion the activities of participants }\end{array}$ \\
\hline \multicolumn{2}{|r|}{ Coffee break } \\
\hline $\begin{array}{l}\text { Indicated after } \\
\text { approval }\end{array}$ & $\begin{array}{l}\text { Mini-lecture "Observation" } \\
\text { Watching a video clip about the order of observation of the mentee, discussion } \\
\text { Practicing the basic requirements of observation } \\
\text { Flipchart work (generalization of positive and negative qualities of a mentor) } \\
\text { Role play in groups of three "Mentor of a neighbor" } \\
\text { Summing up }\end{array}$ \\
\hline \multicolumn{2}{|r|}{ Training session day 2} \\
\hline $\begin{array}{l}\text { Indicated after } \\
\text { approval }\end{array}$ & $\begin{array}{l}\text { Mini-lecture "Topics of day 1" } \\
\text { Demonstration of presentation "Motivation of the mentee", watching a video } \\
\text { clip } \\
\text { Role play in groups of three "Mentor of a neighbor" }\end{array}$ \\
\hline \multicolumn{2}{|r|}{ Coffee break } \\
\hline $\begin{array}{c}\text { Indicated after } \\
\text { approval }\end{array}$ & Summing up \\
\hline
\end{tabular}

We will describe the main aspects of organizing and conducting the training course on the basics of mentoring for the future Marine officers. Due to the peculiarities of the educational process of this category of servicemen, some exercises can simply be performed by members of the training group and are not discussed if they do not want to do so. It is not desirable to subordinate personnel to attend this training course together with superiors (commanders of educational units, curators of educational groups). The training course may be preceded by a questionnaire in order to divide participants into teams according to temper, service experience. Also, at the stage of preparation for the formation of the training group, it is recommended to study the social and demographic data. As a rule, the training course consists of the introductory, main and final parts which are characterized by their methodological techniques (exercises).

We will consider the main guidelines of the introductory part of the training course:

1. The group gathers and sits in a circle. Participants wear badges.

2. Introductory word of the coach (facilitator). Getting acquainted the coach with the group, establishing psychological contact. The coach introduces himself to the audience, briefly talks about himself. After that he briefly describes the main aim of the training course to the participants, and also tells the members of the training group what will happen during two days. 
3. The participants introduce themselves to the coach and the whole group, saying their name and revealing their expectations of the training course.

In addition to announcement of the aim of the training course, the procedure (basic rules) of its conduct, study the cadets' expectations of the training course, the introductory part may also contain various exercises for relaxation, and in some cases for acquaintance of the participants. For example, exercise "My Name / My Letter" can be used. The purpose of the exercise is to break the ice, to get to know the participants better; resources - A4 sheets; time - 10 minutes. Procedure: 1. Each participant chooses any letter of the alphabet and sounds it to the whole group or neighbor. 2. Participants have 2 minutes to find as many words started with the chosen letter as possible that describe them. 3. Each participant shares his words with the group, for example, my name is Victor and my letter "P". I am punctual, plainspoken. It is possible to write names and letters on poster sheets. If the group of participants is too large, you can divide it into small teams.

The main part of the training session we may divide into theoretical and practical parts. However, this division is quite nominal, because during training session special competencies are acquired while performing practical tasks (minilectures, conversations, multimedia presentation, mutual learning, group work). As a rule, the main part consists of three coherent blocks, which are aimed at determining the problem of mentoring; finding ways to solve it; developing the required practical skills. Conducting this component of the training course should be aimed at clear definition of the essence of the basic concepts of mentoring; the role and place of mentoring in the training system in the Navy of the Armed Forces of Ukraine (hereinafter - Ukrainian Navy); forms, methods, types of mentoring (tutoring, coaching, mentoring, scientific guidance, supervision); characteristics of the principles of mentoring, professional and personal qualities of a mentor, characteristics of the stages of professional development of servicemen of Ukrainian Navy, peculiarities of the professional activities of servicemen of marine units. The block of finding ways to solve the problem and providing with necessary information involves the use of exercises to plan the work of a mentor with a mentee based on his level of readiness for professional activities and patterns of professional becoming and developing. The logical continuation of the main part of the training course is the performing of various practical tasks. Typical practical tasks for participants of the training course can be the following: to diagnose their own readiness for mentoring on the basis of certain criteria, to analyze their own strengths and weaknesses; to analyze the factors that, in your opinion, have the most negative impact on the professional activities of servicemen of Ukrainian Navy; to analyze the level of legal regulations and methodological support for the implementation of mentoring in marine units; to identify the forms of mentoring that, in your opinion, best meet the modern needs of marines and are the most effective for the professional development of the mentees; to give an information or educational talk; to make aware of the job description of a certain position; to explain the algorithm of induction and becoming.

The training session includes a mini-lecture "Basic concepts of mentoring". During the lecture it is worth giving examples and the facts from cadets' life. These 
can be meetings with experienced officers, utilization tours to marine units, educational activities, practical classes and more. The coach needs to adapt them skillfully to the forms of mentoring, to show their importance in adapting to new conditions of work. As an example we can mention the practical training course that was conducted with future marine officers on the medium landing ship "Yurii Olefirenko". In addition to the acquired knowledge, skills and abilities necessary for their specialization, the coach should note that the outlined lesson is a type of mentoring conducted by experienced instructors from a separate battalion of marines. The cadets' attention should be focused not only on the information of the algorithm of preparation to load the equipment on board of a ship, which they received during the lesson, but also on the methods of experienced officers, methods of information transmission, communication and more. It should be noted that such classes allow cadets not only to act as observers, but also to gain practical skills in operating an armored personnel carrier during the placement of a combat vehicle in the tweendeck of a landing craft, as well as preparing equipment for crossing the sea. Moreover, a very positive methodological approach during the mini-lecture is the use of the exercise "Circle of Associations", the purpose of which is to create a "bridge" between the exercises. Resources: A1 paper (board), stickers, markers. Time: 5 - 10 minutes. Procedure: On A1 paper or a board, the coach (facilitator) draws the sun, in the center of which is written the word "mentoring". Participants attach stickers with their own associations to this word on the rays of the sun. Later the coach encourages the participants to lead a discussion asking different questions.

The final part of the training session includes: summing up; receiving feedback from participants (using the feedback form); relaxation and training completion procedures. This stage of the training course should connect all the topics covered during the lesson in order to sum up it logically. Summing up is a very important stage during the training course. It should be done after considering the main issues (exercises), as well as after the training course as a whole. At the end of the discussion, the coach (facilitator) should summarize the results of the session or the entire training course as a whole, remind the topic, the aim of the completed issues of the last session, as well as topics and issues considered during the training course. It is mandatory that the coach gives some time to participants to ask questions and for everyone to be able to express their feelings and opinions about the training course (statements are allowed on any occasion if it is important for the mentee to state this right now). An effective methodological technique for the final part of the training course is to use the exercise "Action!". The purpose of this exercise is to formulate plans for the future based on the knowledge gained during the training course. Necessary resources are sheets of paper, pens; time - up to 15 minutes. Procedures: 1. Invite each participant to think about what he or she has received from the course and what he or she intends to do after completing the training course. 2. Invite participants to divide a sheet of paper into three columns labeled "Six Months", "Three Months", and "Tomorrow" and fill in these columns. 3. Give participants 15 minutes, and then ask everyone to read one of the most important things from each column. 
The final part is an opportunity to answer questions and formulate tasks for the future. The coach (presenter) must recommend literature, videos, sites on the Internet (intranet) for self-study. It is important for the participants to complete the work with satisfaction and high motivation to apply the acquired skills.

In addition, during the final stage of the workshop it should posed the following issues for consideration: evaluation of the implementation of the workshop goal by the coach; assessment of participants' expectations (it is advisable to organize discussions with the participants, using a slide or a poster "Participants' expectations" from the first day of training); self-evaluation of participants (impressions of work: negative and positive moments, wishes).

Conclusion. Thus, in the course of research we established that the effective implementation of topical workshops in the system of future Marine offices training requires a comprehensive use of existing guidelines for scientific and pedagogical staff. The main attention during the preparation and conduct of workshops should be paid to the following key issues: definition of expected results (formulation of knowledge, skills and habits; educational goals and expected results; selection of content and its structuring; teaching methods sampling; designing the program and making handouts for participants); coordination of workshops; preparatory organizational measures; preparation for work in small groups; work with materials during training session (presentations, use of audiovisual aids, flip charts), etc. The prospects for further research in this area are the adaptation of the proposed methodological guidelines to the conditions of the educational process of higher military educational institutions.

\section{References:}

1. Kotenko T. (2009), Treninh yak zasib aktyvizatsii navchannia u vyshchii shkoli [Training as a means of intensifying learning in higher education], Naukovi pratsi Kirovohradskoho natsionalnoho tekhnichnoho universytetu. Ekonomichni nauky. 2009. Vyp. 16(2). S. 143-147. [in Ukrainian].

2. Skurativska M. (2018), Treninhovi tekhnolohii vykladannia u vyshchii shkoli [Training technologies of teaching in high school], Rezhym dostupu: http://intkonf.org/skurativska-mo-treningovi-tehnologiyivikladannya-u-vischiy-shkoli/. [in Ukrainian].

3. Korniienko I. (2016), Metodolohiia provedennia treninhiv: kurs lektsii z dystsypliny dlia studentiv dennoi ta zaochnoi formy navchannia spetsialnosti 053 «Psykholohiia» [Methodology of trainings: a course of lectures on the discipline for full-time and part-time students majoring in 053 «Psychology»], Mukachevo: MDU, 2016. 60s. [in Ukrainian].

4. Kovalchuk H. (2006), Treninhovi tekhnolohii navchannia z ekonomichnykh dystsyplin [Training technologies of training in economic disciplines]: navch. posib. K.: KNEU, 2006. 320 s. [in Ukrainian].

5. Bakli R., Keipl D. (2002), Teoryia y praktyka trenynha [Theory and practice of training]. SPb.: Pyter, 2002. 352 s. [n Russian]].

6. Butenko N. (2011), Treninh upravlinskykh kompetentsii [Management competencies training]: navch. posib. K.: KNEU, 2011. 444 s. [in Ukrainian].

7. Fulei. T., Burukovska N. , Budnychenko T., Savchenko H. (2017), Metodychni rekomendatsii dlia treneriv shchodo rozroblennia ta provedennia treninhiv [Methodical recommendations for trainers on the development and conduct of trainings]. K.: FOP Demchynskyi O. V., 2017. 92 s. [in Ukrainian]. 